This manuscript entitled Go with the flow: the role of gateway and straits on plastic distribution (Chiarella and Hernández-Molina) is a post print of a published manuscript accepted for publication in Geology Today. The published version of the manuscript is available here https://doi.org/10.1111/gto.12345 


\title{
Go with the flow: the role of gateway and straits on plastic distribution
}

\author{
Domenico Chiarella and Francisco Javier Hernández-Molina \\ Department of Earth Sciences, Royal Holloway, University of London, Egham
}

\begin{abstract}
Plastic pollution is widespread throughout the marine environments representing a risk for ecosystems and human health when plastic enters the food chain. Understanding factors and processes controlling plastic distribution and accumulation is crucial to identify plastic hotspots. Gateways and straits can play an important role on transferring plastic debris at superficial and sea bottom level depending on the local water masses stratification.
\end{abstract}

\section{Plastic and marine ecosystems}

The sedimentary record contains several examples of sediment mixtures characterised by different compositions representing the so-called hybrid deposits. The most common type of mixing results from the interaction between a siliciclastic and bioclastic fraction to form a compositional mixing. However, the large use of plastic material by human beings, and the fact that most of the plastic waste is still not disposed of responsibly, is producing a new type of mixed sediment composed of a natural lithoclastic (silico- or bio-) and anthropogenic plasticlastic fraction (Fig. 1).

Macro- and microplastic ( $<5 \mathrm{~mm}$ ) debris represent one of the major concerns for terrestrial and marine ecosystems at all latitudes. Plastic started to contaminate the marine environment since the 1930s and has been documented in all marine environments and along the entire water column from the sea surface to the abyssal plains. As more than ten million tonnes of plastic enter the global ocean each year, there is a growing concern about 
the impact on marine communities. Several studies show that marine species started to interact and eat plastic particles causing their dead, changes in ecological behaviour and potential implications for human health when plastic enters the food chain. In the Mediterranean Sea, the primary input of plastic debris can be associated with largely coastal urbanised areas (Figs. 2A and 2B). Transfer mechanisms of plastic from land to sea seems to be mainly related to normal or energetic fluvial processes (e.g. flash flood), which when evolving into submarine hyperpycnal flows are able to transfer through canyons large amount of continental litter into the deep sea, and watershed outfall discharging municipal and industrial microplastic from large coastal cities directly into the sea where is mixed with sediments. Here, bottom currents (i.e. thermohaline / geostrophic circulation and other oceanographic processes) acting on the seafloor might control microplastic distribution and hotspots location. Surface water masses are responsible for the plastic debris distribution in the shallower water column. However, plastic can sink down and go back up again depending on local oceanographic processes and their variability.

\section{Gateway and Straits and plastic distribution}

Ocean basins are currently connected by shallow or deep relatively narrow passages like gateways, seaways, and straits representing key channels for exchange of water, heat, salt, nutrients, and organic carbon between oceans and seas. Gateways and straits can play an important role on transferring plastic debris as well, and the Mediterranean Sea straits are key regions to understand basin-scale circulation since they control the general water masses circulation. The Mediterranean Sea is characterised by four main marine passageways connecting (i) the Atlantic Ocean with the Western Mediterranean Sea (i.e. 
Gibraltar Strait), (ii) the Western and Eastern Mediterranean Sea (i.e. Sicily and Messina straits), and (iii) the Adriatic and Ionian seas through the Otranto Strait.

The Gibraltar Strait $(14,3 \mathrm{Km}$ wide and $-288 \mathrm{~m}$ depth in the narrowest and shallower portions respectively) strongly influences Mediterranean-Atlantic water mass exchange. The water circulation is driven by the Atlantic Water (AW) inflow and the Mediterranean Outflow Water (MOW) (Fig. 3A). The Atlantic Water flows toward the east as surface current following the North African coast across the Alboran Sea. The Mediterranean Outflow Water consists of warm and dense water flowing in an intermediate water beneath the colder and less dense Atlantic Surface Water. At the sea surface, the Atlantic Water inflow acts as barrier for plastic litter floating in the Alboran Sea preventing the plastic to enter into the Gulf of Cadiz. At the same time, the Atlantic inflow transfer plastic pollution into the Mediterranean Sea. Conversely, in the Gulf of Cadiz large amount of plastic on the sea bottom have been recognised along the pathway of the Mediterranean Outflow Water (Fig. 2B) suggesting a control of the bottom current on the high concentration of plastic found offshore the Guadalquivir Basin.

The interaction between the western and eastern Mediterranean Sea is mainly controlled by the Sicily Strait although the Messina Strait plays a role in the Ionian-Tyrrhenian water exchange (Fig. 3B). In the Sicily Strait (150 Km wide and depth spanning from Sicily to Tunisia between -100 and $-500 \mathrm{~m}$ ), the surface circulation is characterised by the Atlantic Water directed eastwards. The deeper water masses consist of the Levantine Intermediate Water (LIW) and the Eastern Mediterranean Deep Water (EMDW), both flowing eastwards. The 3-km-wide tide-dominated Messina Strait records the exchange between a branch of the superficial Atlantic Water, which enter the Tyrrhenian Sea following the northern coast of Sicily, and the Levantine Intermediate Water. Water exchange between the Tyrrhenian 
and Ionian seas is not simultaneous but follow a tidal cyclicity. Every semi-diurnal tidal cycle, the southward-directed Atlantic Water flows into the Ionian Sea above the Levantine Intermediate Water followed by a tidal inversion phase characterised by northwarddirected Levantine Intermediate Water entering the Tyrrhenian Sea. Both flood and ebb currents transit across the Messina Strait with comparable average velocity exerting a bedshear stress on the sea bottom. After entering the Gibraltar Strait, the eastward directed Surface Atlantic Water flow distributes the plastic along the entire North Africa coast before reaching the Sicily Strait. Here, the Atlantic Water splits in two main branches with the one entering the Tyrrhenian Sea moving plastic litter into the Ionian Sea through the Messina Strait. The southern branch of the Atlantic Water entering the Sicily Strait splits in a northern and southern branch each forming two wings of superficial plastic hotspots that shade towards the east (Fig. 2A). At the sea bottom, available data and model for the Sicily Strait doesn't emphasise a particular increase in plastic on the sea bottom linked to deep currents although it cannot be ruled out. In the Messina Strait the higher concentration of sea bottom plastic occurs on the Tyrrhenian exit of the strait along the pathway of the northward directed deep current (Fig. 2B).

Finally, the Otranto Strait is characterized by a surface circulation controlled by a cyclonicdriven northern inflow of the Atlantic Water along the eastern margin of the strait and a narrow outflow of the Adriatic Deep Water (ADW) along the western margin. In the Otranto Strait, the northern directed Atlantic Water inflow push and distributes the plastic on the eastern margin of the strait before continuing to flow towards the north.

\section{Concluding remarks}


Plastic distribution in the Mediterranean Sea indicates that straits could represent key areas controlling plastic distribution at different water depth (Fig. 2). Gateways and straits are key areas for water exchange with high bottom current velocities. Water exchange is then responsible for distribution of sediments including large concentrations of macro and microplastic at surface, intermediate and deep depths, which eventually accumulate on the sea floor preferentially in those areas with low energy conditions. In particular, microplastic and muddy concentrations associated with overflows are expected to be distributed distally and laterally respect to the main core flow. In the Gibraltar Strait, overflow velocity reduces considerably after $\sim 100-150 \mathrm{~km}$ favouring the accumulation of fine particles in the areas adjacent to the main channel. Accordingly, it is important to further understand how hydrodynamic of straits controls the spatial distribution of plastic from densely to less populated areas, and from shallow to deep seafloor environments. This reinforces the need to move forward the integration of oceanographic processes, physiographic elements and marine sedimentology to determine plastic distribution.

\section{Suggestions for further reading}

1. Baringer, M. O. N., and Price, J. F., 1999, A review of the physical oceanography of the Mediterranean outflow. Marine Geology, v. 155(1-2), p. 63-82.

2. Berggren, W.A., 1982. Role of Ocean Gateways in Climate change. En: Climate in Earth History. Studies in Geophysics, National Academic Press, 118-125 pp.

3. Chiarella, D., Longhitano, S.G., Tropeano, M. (2017) Types of mixing and heterogeneities in siliciclastic-carbonate sediments. Marine and Petroleum Geology, 88, 617-627.

4. Choy C.A., Robison B.H., Gagne T.O., Erwin B., Firl E., Halden R.U., Hamilton J.A., Katija K., Lisin S.E., Rolsky C., Van Houtan K.S. (2019) The vertical distribution and biological transport of marine microplastics across the epipelagic and mesopelagic water column. Scientific Report, 9:7843, https://doi.org/10.1038/s41598-019-44117$\underline{2}$ 
5. Compa M., Alomar C., Wilcox C., van Sebille E., Lebreton L., Hardesty B.D., Deudero S. (2019) Risk assessment of plastic pollution on marine diversity in the Mediterranean Sea. Science of the Total Environment, 678 (2019) 188-196.

6. Cózar A., Sanz-Martín M., Martí E.,González-Gordillo J.I., Ubeda B., Gálvez J.Á. et al.(2015) Plastic Accumulation in the MediterraneanSea. PLoS ONE 10(4): e0121762. doi:10.1371/journal.pone.0121762

7. El-Geziry, T.M. \& Bryden, I.G., 2010, The circulation pattern in the Mediterranean Sea: issues for modeller consideration, Journal of Operational Oceanography, 3, 3946.

8. Eriksen M., Lebreton L.C., Carson H.S., Thiel M., Moore C.J., Borerro J.C., Galgani F., Ryan P.G., Reisser J., 2014, Plastic Pollution in the World's Oceans: More than 5 Trillion Plastic Pieces Weighing over 250,000 Tons Afloat at Sea. PLoS ONE, 9, e111913, doi:10.1371/journal.pone.0111913

9. Kane I.A., Clare M.A., Miramontes E., Wogelius R., Rothwell J.J, Garreau P., Pohl F. (2020) Seafloor microplastic hotspots controlled by deep-sea circulation. Science, 10.1126/science.aba5899

10. Liubartseva, S., Coppini, G., Lecci, R., Clementi, E. (2018) Tracking plastics in the Mediterranean: 2D Lagrangian model. Mar. Pollut. Bull. 129, 151-162.

11. Longhitano S.G. (2018) Between Scylla and Charybdis (part 1): the sedimentary dynamics of the modern Messina Strait (central Mediterranean) as analogue to interpret the past. Earth-Science Reviews, 185, 259-287.

12. Longhitano S.G., and Chiarella D., 2020, Tidal straits: basic criteria for recognizing ancient systems from the rock record. In: Regional Geology and Tectonics, Elsevier, 365-415.

13. Mecho A., Francescangeli M., Ercilla G., Fanelli E., Estrada F., Valencia J., Sobrino I., Danovaro R., Company J.B., Aguzzi J., 2020, Deep-sea litter in the Gulf of CAdiz (Northeastern Atlantic, Spain). Marine Pollution Bulletin, 153, https://doi.org/10.1016/j.marpolbul.202 Grazia 0030.110969

14. Pierdomenico M., Casalbore D., Chiocci F.L., 2019, Massive benthic litter funnelled to deep sea by flash-flood generated hyperpycnal flows. Scientific Report, 9:5330, doi.org/10.1038/s41598-019-41816-8

15. Pham C.K., Ramirez-Llodra E., Alt C.H.S., Amaro T., Bergmann M., et al. (2014) Marine Litter Distribution and Density in European Seas, from the Shelves to Deep Basins. PLoS ONE 9(4): e95839. doi:10.1371/journal.pone.0095839

16. Poulain P.M., Menna M., Mauri E., 2012, Surface Geostrophic Circulation of the Mediterranean Sea Derived from Drifter and Satellite Altimeter Data. J. Phys. Oceanogr., 42, 973-990.

17. Sánchez-Leal, R. F., Bellanco, M. J., Fernández-Salas, L. M., García-Lafuente, J., Gasser-Rubinat, M., González-Pola, C., Hernández-Molina, F. J., Pelegrí, J. L., Peliz, A., Rel- vas, P., Roque, D., Ruiz-Villarreal, M., Sammartino, S., and Sánchez-Garrido, J. C., 2017. The Mediterranean Overflow in the Gulf of Cadiz: A rugged journey, Scientific Reports, 3, https://doi.org/10.1126/sciadv.aao0609, 2017.TS24 
18. Sanchez-Vidal A, Thompson RC, Canals M, de Haan WP (2018) The imprint of microfibres in southern European deep seas. PLOS ONE 13 (11): e0207033. doi.org/10.1371/journal.pone.0207033

19. Schlitzer, R., 2017, Ocean Data View, https://odv.awi.de

20. Schroeder K., Chiggiato J., Josey S.A., Borghini M., Aracri S., Sparnocchia S. (2017) Rapid responce to climatic in a marginal sea. Scientific Reports, 7, 4065.

21. Taylor M. L., Gwinnett C., RobinsonL.F., Woodall L.C. (2016) Plastic microfibre ingestion by deep-sea organisms. Scientific Report, 6:33997, doi: 10.1038/srep33997

22. Thompson R.C., Richard Y.O., Mitchell P., Davis A., Rowland S.J., John A.W.J., McGonigle D. and Russell A.E. (2004) Lost at Sea: Where Is All the Plastic? Science, 304, 838. doi:10.1126/science.1094559

23. Zalasiewicz J., Waters C.N., Ivar do Sul J.A., Corcoran P.L., Barnosky A.D., Cearreta A., Edgeworth M., Gałuszka A., Jeandel C., Leinfelder R., McNeill J.R., Steffen W., Summerhayes C., Wagreich M., Williams M., Wolfe A.P., Yonan Y. (2016) The geological cycle of plastics and their use as a stratigraphic indicator of the Anthropocene. Anthropocene, 13, 4-17, 10.1016/j.ancene.2016.01.002

24. Zambianchi E, Trani M and Falco P (2017) Lagrangian Transport of Marine Litter in the Mediterranean Sea. Front. Environ. Sci. 5:5. doi: 10.3389/fenvs.2017.00005

\section{Acknowledgments}

This work was executed within the framework of Clastic Sedimentology Investigation (CSI) and The Drifters research groups at Royal Holloway, University of London (RHUL). Thanks to the QOTSA for inspiring this idea.
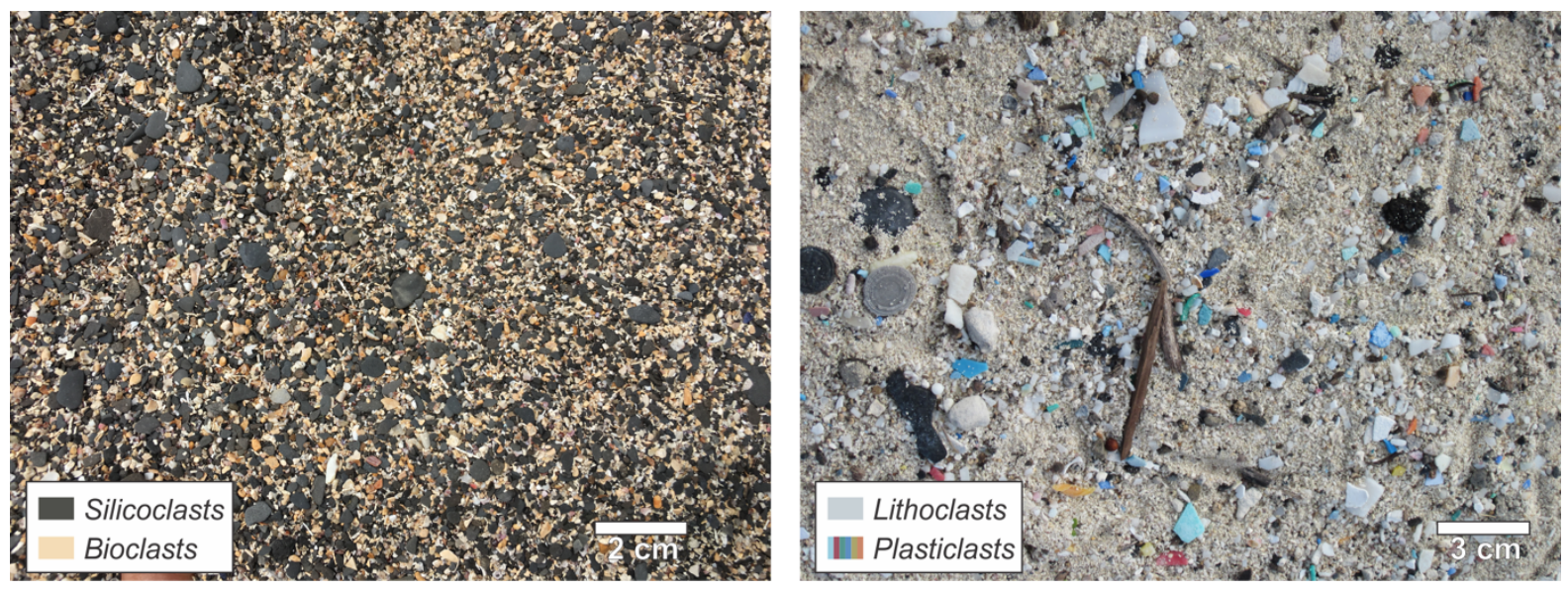

Figure 1 -Compositional mixture (sensu Chiarella et al., 2017) of siliciclastic and bioclastic sediments (left) and natural and plastic sediments (right) along present-day beach deposits (Right photo credit: NOAA Marine Debris Program). 

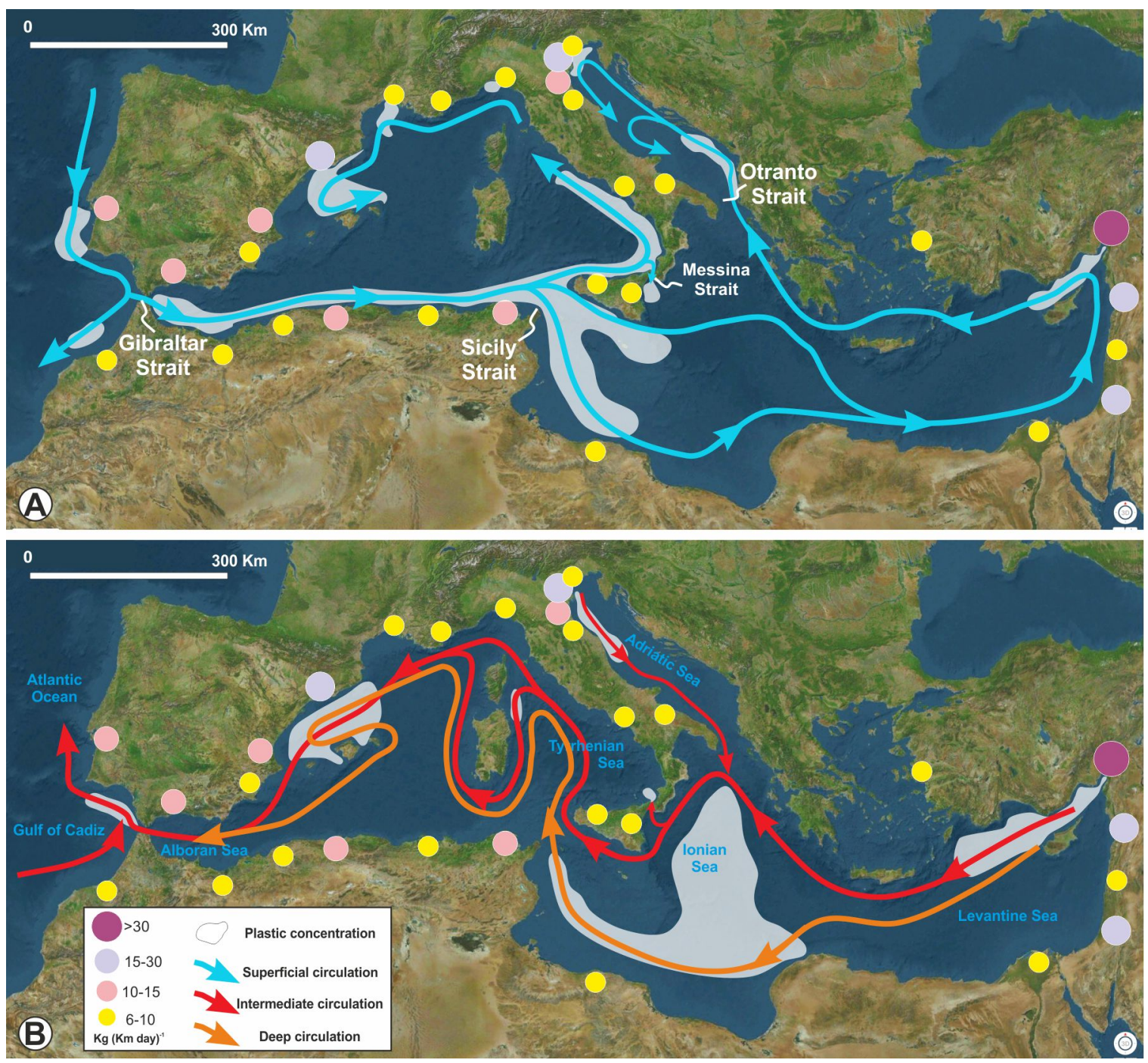

Figure 2 - Plastic sources and water masses distribution against the oceanographic circulation in the Mediterranean Sea. A) Surface water circulation controlled by the Atlantic Water inflow entering the Mediterranean Sea through the Gibraltar Strait. High concentration of sea surface plastic in the Alboran Sea, offshore Tunisia and in the lonian Sea controlled by the Gibraltar, Sicily and Messina straits respectively. B) Intermediate-and deep-water circulation flowing from the Levantine Sea to the Atlantic Ocean though the Adriatic, Ionian and Tyrrhenian seas. High concentration of sea bottom plastic in the Ionian Sea and Gulf of Cadiz (Atlantic Ocean) and to minor extent in the Tyrrhenian Sea controlled by the Gibraltar and the Messina straits respectively. Current distribution compiled from El-Geziry and Bryden (2010), Poulain et al. (2012), Sanchez-Leal et al. (2017), Schroeder et al. (2017) and reference therein. Plastic distribution is compiled integrating direct observation and models. (see Suggestions for further reading). 


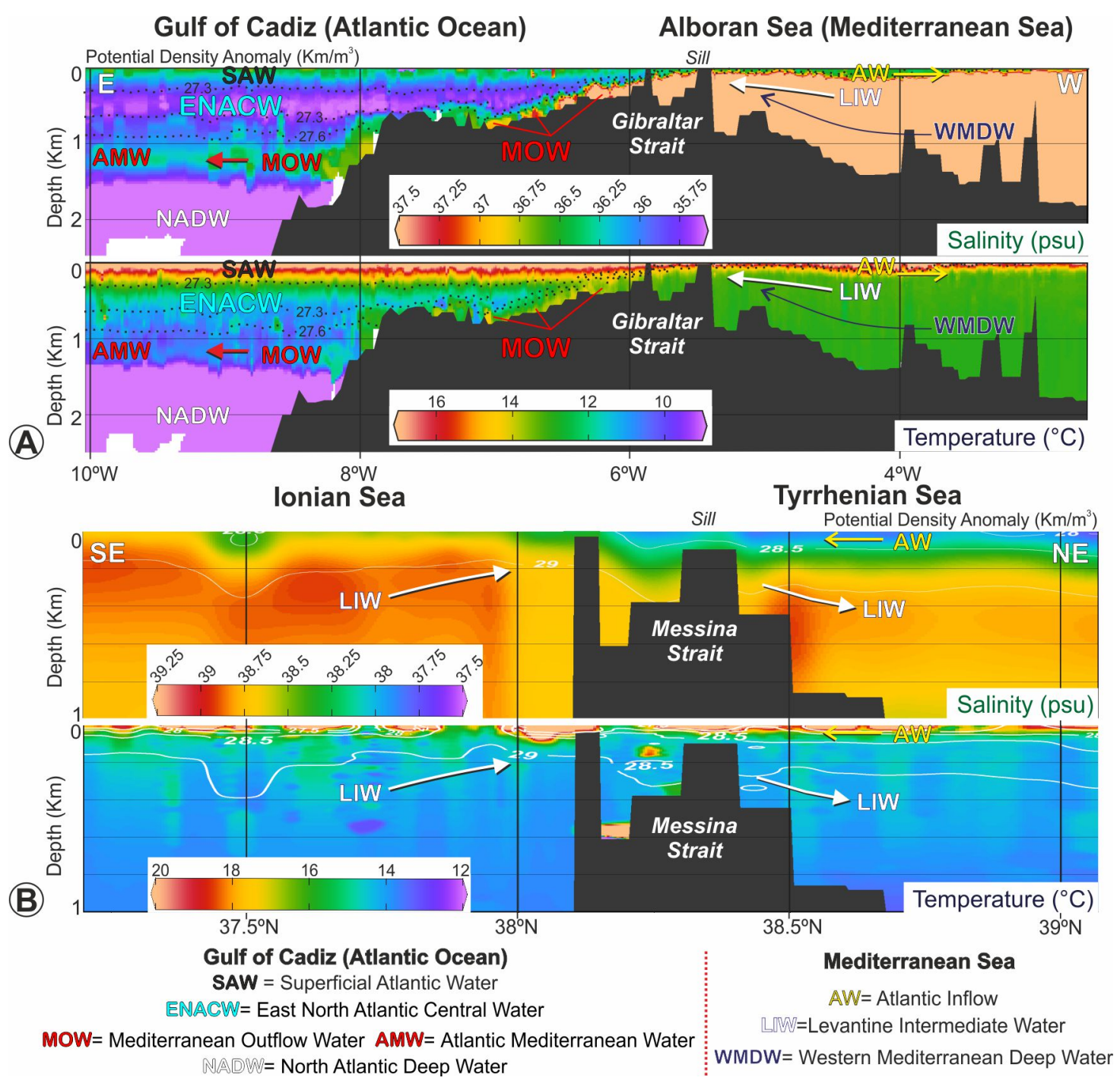

Figure 3 - Water masses profiles across the Gibraltar and Messina straits showing distribution flowing at superficial and deep-water levels. A) In the Gibraltar Strait the Atlantic Water (AW) enter into the Mediterranean Sea as superficial cold and less dense water mass while the warn and denser Mediterranean Outflow Water enter into the Atlantic Ocean as deep water. (B) In the Messina Strait the water exchange between the Tyrrhenian and lonian seas is characterised by a superficial southern directed Atlantic Water and a deep northern directed Levantine Intermediate Water. Hydrographic profiles are based on the salinity and temperature values of NOAA World Ocean Database 2018 (https://www.nodc.noaa.gov/OC5/WOD/datawodgeo.html), visualised using Ocean Data View (Schlitzer, 2017). The temperature and salinity plots are generated by interpolating data from adjacent conductivity, temperature, and depth (CTD) stations. These data were used to characterise the modern regional water masses along the Gibraltar and Messina straits. 